\title{
A change in the frequency of the degenerating spermatogonia in the rat
}

\author{
S. Ohwada and H. Tamate
}

\author{
Laboratory of Animal Science, Faculty of Agriculture, Tohoku University, Sendai 980, Japan
}

\begin{abstract}
Summary. In right and left testes of the same animals, the frequencies of degeneration of type A spermatogonia were almost equal. When one testis was removed, there was a negative correlation of the frequency of the degenerating spermatogonia in this testis and the other after 25 days.
\end{abstract}

\section{Introduction}

The degeneration of germinal cells in the seminiferous epithelium is regularly seen in normal spermatogenesis in many mammalian species (for review, see Roosen-Runge, 1973). RoosenRunge (1973) described this phenomenon as "the degree and the modes of the cell loss are species-specific". In rats, this type of germinal-cell loss occurs at definite stages of the cycle of the seminiferous epithelium (Roosen-Runge, 1955; Clermont, 1962; Huckins, 1971). Type A spermatogonia degenerate during their mitotic stages (Clermont, 1962; Huckins, 1971), spermatocytes degenerate during their meiotic divisions (Roosen-Runge, 1955; Clermont, 1962), and spermatids do so during stage IX-XI of the cycle (Clermont, 1962). Spermatogonial degeneration is a specific feature in the rat and some quantitative data have been reported (Clermont, 1962; Ohwada \& Tamate, 1975; Huckins 1978). At stage XII of the cycle, the average frequencies of the degenerating type A spermatogonia were $8.1 \%$ in Sherman rats (Clermont, 1962) and $7.7 \%$ in Holtzman rats (Ohwada \& Tamate, 1975). In Charles River rats, the frequency of the type $\mathrm{A}_{2}$ spermatogonia has been reported as $8.9 \%$ in whole mount tubules (Huckins, 1978). The value for Holtzman rats showed a rather large variance among individuals. In this paper we report the change in the frequency of the degenerating type A spermatogonia at stage XII of the cycle in Wistar rats.

\section{Materials and Methods}

The 24 Wistar rats used were 10 months of age. They were fed ad libitum on ground rat chow and tap water and were kept in $12 \mathrm{~h}$ light $(06: 00-18: 00 \mathrm{~h}) / 24 \mathrm{~h}$. Pieces of testis were collected between 14:00 and 15:00 h and were fixed in Zenker-formalin fluid for 20-22 h. After embedding in paraffin wax, $5 \mu \mathrm{m}$ sections were stained with the Periodic acid-Schiff-haematoxylin technique. The stages of the cycle of the seminiferous epithelium were identified according to the classification of Leblond \& Clermont (1952) and Perey, Clermont \& Leblond (1961). At stage XII of the cycle, the number of type A spermatogonial nuclei, normal and degenerating, were counted and used to calculate the frequencies of the degenerating cells.

In Exp. 1, both testes of 10 rats were removed and the percentages of the degenerating spermatogonia at stage XII of the cycle were calculated for each pair of testes.

In Exp. 2, one testis was removed from each of 14 rats under anaesthesia with pentobarbitone sodium. The remaining testis was removed at slaughter 25 days later. 


\section{Experiment 1}

\section{Results}

As shown in Table 1 , there was no difference in the average ( \pm s.d.) frequencies between right $(6.8 \pm 1.9 \%)$ and left $(7.3 \pm 2.1 \%)$ testes and the correlation coefficient was 0.7747 $(P<0.01)$. The regression equation was $y$ (\% degeneration in left testis) $=1.50+0.84 x$, where $x=\%$ degeneration in right testis (Text-fig. 1a).

Table 1. Frequency of degenerating type A spermatogonia at stage XII in right and left testis of rats

\begin{tabular}{|c|c|c|c|c|c|c|}
\hline \multirow[b]{2}{*}{ Animal } & \multicolumn{3}{|c|}{ Right testis } & \multicolumn{3}{|c|}{ Left testis } \\
\hline & $\begin{array}{l}\text { No. of } \\
\text { tubular } \\
\text { cross- } \\
\text { sections }\end{array}$ & $\begin{array}{l}\text { Total no. } \\
\text { of } \\
\text { spermato- } \\
\text { gonia }\end{array}$ & $\begin{array}{c}\text { No. of } \\
\text { degenerating } \\
\text { spermatogonia (\%) }\end{array}$ & $\begin{array}{c}\text { No. of } \\
\text { tubular } \\
\text { cross- } \\
\text { sections }\end{array}$ & $\begin{array}{l}\text { Total no. } \\
\text { of } \\
\text { spermato- } \\
\text { gonia }\end{array}$ & $\begin{array}{c}\text { No. of } \\
\text { degenerating } \\
\text { spermatogonia (\%) }\end{array}$ \\
\hline 1 & 88 & 351 & $24(6 \cdot 8)$ & 105 & 472 & $35(7.4)$ \\
\hline 2 & 118 & 503 & $41(8 \cdot 2)$ & 144 & 719 & $79(11 \cdot 0)$ \\
\hline 3 & 114 & 489 & $13(2 \cdot 7)$ & 92 & 428 & $16(3.7)$ \\
\hline 4 & 108 & 390 & $22(5.6)$ & 86 & 366 & $23(6 \cdot 3)$ \\
\hline 5 & 99 & 419 & $30(7 \cdot 2)$ & 126 & 504 & $49(9.7)$ \\
\hline 6 & 89 & 359 & $38(10.6)$ & 91 & 359 & $33(9.2)$ \\
\hline 7 & 113 & 555 & $44(7.9)$ & 125 & 590 & $44(7.5)$ \\
\hline 8 & 102 & 557 & $35(6 \cdot 3)$ & 87 & 391 & $27(6 \cdot 9)$ \\
\hline 9 & 97 & 451 & $28(6 \cdot 2)$ & 102 & 462 & $25(5.4)$ \\
\hline 10 & 100 & 501 & $34(6 \cdot 8)$ & 108 & 454 & $26(5.7)$ \\
\hline
\end{tabular}
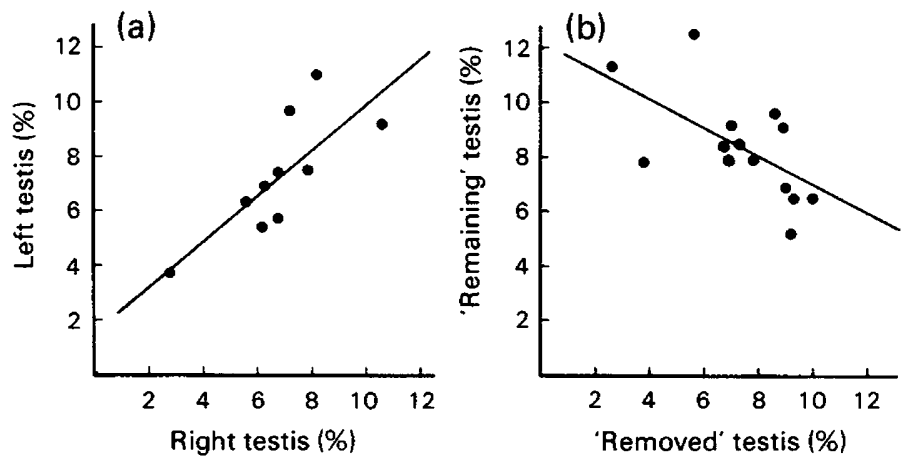

Text-fig. 1. Correlation of the frequency of degenerating spermatogonia at stage XII between (a) right and left testes of the same rats and (b) 'removed' and 'remaining' testes 25 days after hemicastration in the same rats.

\section{Experiment 2}

As shown in Table 2, the testis remaining for 25 days after unilateral castration did not show any 'compensatory hypertrophy' with respect to the frequencies of the degenerating spermatogonia $(7.3 \pm 2.1$ (s.d.)\% in the 'removed' and $8.3 \pm 1.9 \%$ in the 'remaining' testis). The regression equation for the values in the testes on each side was $y=12 \cdot 18-0.52 x$, and the negative correlation $(-0.5563)$ was significant $(P<0.05)$ (Text-fig. $1 b)$.

\section{Discussion}

In the rat testis, type A spermatogonia degenerate mostly at stage XII of the cycle (Clermont, 1962; Huckins, 1971) and the frequencies were variable among individuals, ranging from 2 to 
Table 2. Frequency of degenerating type A spermatogonia at stage XII in one testis ('removed') and that 'remaining' for 25 days

\begin{tabular}{|c|c|c|c|c|c|c|}
\hline \multirow[b]{2}{*}{ Animal } & \multicolumn{3}{|c|}{ 'Removed' testis } & \multicolumn{3}{|c|}{ 'Remaining' testis } \\
\hline & $\begin{array}{c}\text { No. of } \\
\text { tubular } \\
\text { cross- } \\
\text { sections }\end{array}$ & $\begin{array}{l}\text { Total no. } \\
\text { of } \\
\text { spermato- } \\
\text { gonia }\end{array}$ & $\begin{array}{c}\text { No. of } \\
\text { degenerating } \\
\text { spermatogonia (\%) }\end{array}$ & $\begin{array}{c}\text { No. of } \\
\text { tubular } \\
\text { cross- } \\
\text { sections }\end{array}$ & $\begin{array}{l}\text { Total no. } \\
\text { of } \\
\text { spermato- } \\
\text { gonia }\end{array}$ & $\begin{array}{c}\text { No. of } \\
\text { degenerating } \\
\text { spermatogonia (\%) }\end{array}$ \\
\hline 1 & 125 & 463 & $40(8 \cdot 6)$ & 125 & 603 & $58(9 \cdot 6)$ \\
\hline 2 & 109 & 407 & $38(9 \cdot 3)$ & 92 & 504 & $33(6 \cdot 5)$ \\
\hline 3 & 98 & 395 & $22(5 \cdot 6)$ & 108 & 447 & $56(12 \cdot 5)$ \\
\hline 4 & 125 & 532 & $36(6 \cdot 7)$ & 141 & 592 & $50(8.4)$ \\
\hline 5 & 109 & 402 & $37(9.2)$ & 100 & 483 & $25(5.2)$ \\
\hline 6 & 103 & 465 & $42(9.0)$ & 113 & 449 & $31(6.9)$ \\
\hline 7 & 129 & 551 & $43(7.8)$ & 113 & 535 & $42(7.9)$ \\
\hline 8 & 122 & 528 & $20(3.8)$ & 113 & 540 & $42(7 \cdot 8)$ \\
\hline 9 & 116 & 552 & $38(6.9)$ & 97 & 504 & $40(7.9)$ \\
\hline 10 & 102 & 416 & $37(8.9)$ & 134 & 602 & $55(9 \cdot 1)$ \\
\hline 11 & 106 & 497 & $13(2 \cdot 6)$ & 109 & 452 & $51(11 \cdot 3)$ \\
\hline 12 & 112 & 497 & $35(7.0)$ & 125 & 500 & $46(9.2)$ \\
\hline 13 & 151 & 563 & $41(7 \cdot 3)$ & 97 & 601 & $51(8 \cdot 5)$ \\
\hline 14 & 120 & 701 & $70(10 \cdot 0)$ & 96 & 459 & $30(6 \cdot 5)$ \\
\hline
\end{tabular}

14\% (Clermont, 1962; Ohwada \& Tamate, 1975). The data of Exp. 1 showed that, in the right and left testes of the same animals, the frequencies of the degenerating cells were almost equal. In Exp. 2, although the values varied widely amongst individuals, their range was again between 2.6 and $12.5 \%$ and there was no difference in average values between the 'removed' and the 'remaining' testes. However, there was a negative correlation between these two values in the same animals as shown in Text-fig. 1(b).

There was no testicular hypertrophy after unilateral castration in mature rabbits (Edwards, 1940) and rats 45 days of age or older (Vreeburg, van Andel, Kort \& Westbroek, 1974; Cunningham, Tindal, Huckins \& Means, 1978). In the present study, no hypertrophy was observed by 25 days after surgery and the changes observed in Exp. 2 can be considered not to be an effect of the unilateral castration. The negative correlation observed in Exp. 2 is therefore important and shows that changes are due to some other factor(s) and may be periodic. We suggest that the frequency of the degenerating spermatogonia at stage XII of the cycle in the rat is not a fixed value in each animal, but fluctuates within a certain limit and could be periodic. The apparent individual variance in the frequencies observed may be the result of this periodic change.

We are puzzled to find this unexpected time-dependent change of the frequencies of the degenerating spermatogonia in the rat. Potten, Al-Barwari, Hume \& Searle (1977) reported that approximately $10 \%$ of normal mitoses are not successful and result in cell death by apoptosis in the ileal crypt cell population in the mouse, and that the peak of apoptosis appears 1-3 $\mathrm{h}$ after the peak of mitotic figures in the circadian rhythm. Tamate \& Fell (1977) have drawn attention to the significance of the apoptosis in the control of cell kinetics of the ruminal epithelium in the sheep. The only possible explanation for our finding is that the degeneration of type A spermatogonia in the rat is a phenomenon based on a certain time-dependent schedule which also influences a similar schedule of proliferation rate in these cells through some unknown kinetic factors.

To confirm a periodicity in the frequency of degenerating spermatogonia, we are now examining rats killed 8 and 12 weeks after the unilateral castration. 


\section{References}

Clermont, Y. (1962) Quantitative analysis of spermatogenesis of the rat: a revised model for the renewal of spermatogonia. Am. J. Anat. 111, 111-129.

Cunningham, G.R., Tindal, D.J., Huckins, C. \& Means, A.R. (1978) Mechanisms for the testicular hypertrophy which follows hemicastration. Endocrinology 102, 16-23.

Edwards, J. (1940) The effect of unilateral castration on spermatogenesis. Proc. R. Soc. B 128, 407-421.

Huckins, C. (1971) The spermatogonial stem cell population in adult rats. $I$. Their morphology, proliferation and maturation. Anat. Rec. 169, 533-558.

Huckins, C. (1978) The morphology and kinetics of spermatogonial degeneration in normal adult rats: an analysis using a simplified classification of the germinal epithelium. Anat. Rec. 190, 905-926.

Leblond, C.P. \& Clermont, Y. (1952) Spermatogenesis of rats, mouse, hamster and guinea pig as revealed by the "periodic acid-fuchsin sulfurous acid" technique. Am. J. Anat. 90, 167-215.

Ohwada, S. \& Tamate, H. (1975) A quantitative study on the degenerating spermatogonia in Holtzman rats. Tohoku J. agric. Res. 26, 131-135.
Perey, B., Clermont, Y. \& Leblond, C.P. (1961) The wave of the seminiferous epithelium in the rat. $A m$.J. Anat. 108, 47-77.

Potten, C.S., Al-Barwari, S.E., Hume, W.J. \& Searle, J. (1977) Circadian rhythms of presumptive stem cells in three different epithelia of the mouse. Cell Tissue Kinet. 10, 557-568.

Roosen-Runge, E.C. (1955) Untersuchungen über die Degeneration Samenbildender Zellen in der normalen Spermatogenese der Ratte. Z. Zellforsch. mikrosk. Anat. 41, 221-235.

Roosen-Runge, E.C. (1973) Germinal-cell loss in normal metazoan spermatogenesis. J. Reprod. Fert. 35, 339348.

Tamate, H. \& Fell, B.F. (1977) Cell deletion as a factor in the regulation of rumen epithelial populations. Vet. Sci. Commun. 1, 356-364.

Vreeburg, J.T.M., van Andel, M.V., Kort, W.J. \& Westbroek, D.L. (1974) The effect of hemicastration on daily sperm output in the rat as measured by a new method. J. Reprod. Fert. 41, 355-359.

Received 28 February 1979 